\title{
Analysis of Archetypal Characters in Anita Nair's Mistress and Lessons in Forgetting
}

\author{
Hema. R ${ }^{\mathrm{a}}$, and Dr. M. Poonkodi ${ }^{\mathrm{b}}$ \\ Research Scholar, Karunya Institute of Technology \& Sciences, (Deemed to be \\ University), Coimbatore- 641114 \\ b Assistant Professor Karunya Institute of Technology \& Sciences, (Deemed to be \\ University), Coimbatore- 641114
}

Article History: Received: 11 January 2021; Accepted: 27 February 2021; Published online: 5 April 2021

\begin{abstract}
The present paper analyses the archetypal elements present in the select women characters in the novels Mistress and Lessons in Forgetting. The archetypal presence is in the form of Indian mythological characters. This presence resides in the unconscious psyche of the characters Radha and Akhila. Radha identifies herself with mythological Radha and Ahalya. Akhila identifies herself with goddess Kanyakumari. The paper also analyses how these archetypal presence make them subjugated women and also how they help them to move beyond their stereotypical roles they play in the family and society. The characters Radha and Meera are ordinary women who emerge as potential, emancipated women at a later stage. They struggle in the process of transition from tradition to modernity. In their quest for identity, they emerge as strong and independent women. The paper is analyzed from Jungian perspective of archetypes.
\end{abstract}

Keywords: archetypes, Carl Jung, mythology, feminism, identity

\section{Introduction}

Mythology is an inseparable element in the life and culture of every Indian. The stories and rituals that surround their lives are steeped in mythic beliefs. The epics and the puranas play a vital role in defining the running of the Indian society. Indian women have the presence of these mythological characters in them. In the process of transition from tradition to modernity, they redefine their mythological role in the family and society. Indian writers in English, have written several novels based on mythological presence in women. The mythological presence in these writers, make them set their characters in Indian background. The culture and tradition also play a vital role in defining these characters.

\section{Literature Review}

Anita Nair is a renowned Indian English writer. She writes about the ordinary lives of men and women. Her novels are set in the Indian background. She portrays women's struggle in a patriarchal society and the subsequent tension that underlie. Her women are strong and they overcome the barriers that restrict and limit their individual space in the family and society.

Nair's women characters identify themselves with the Hindu and Greek mythological characters. They undergo transition from tradition to modernity. In this process of transformation, they face identity crisis.

According to eminent theorist and psychologist Carl Jung, archetypes are universal in nature and they are present in the human psyche. Nair's characters too have the presence of mythological characters in their unconscious psyche. The presence of these mythological characters restricts them to the predefined roles of womanhood. Nair's women strive to come out of the set mythological conformity. They embark on a journey to their inner self. In the process of transformation, they construct their identity.

Analysis of the the mythological 'other' present in Radha of Mistress and Akhila of Ladies' Coupe

Anita Nair's Mistress juxtaposes the state of the dying art form of Kathakali and the condition of women in the society. The novel unravels through the voices of the main characters Radha, her husband Shyam and uncle Koman. Unce Koman is a Kathakali artist. He represents the true form of art. Nair touches the subtle human relationships and the subsequent turmoil in the lives of Radha and Shyam. Uncle Koman encourages unadulterated art. Nair explicitly shows that human life unlike art cannot be pre-determined.

Radha is brought up as an obedient daughter. She is taken care of all through her life. This restricts her freedom. She does not gain financial independence and the freedom of free speech. Her thoughts are cluttered sometimes and she becomes mute and voiceless. During her childhood, Radha obeyed her father and later she came under the control of her husband. Radha's husband Shyam is a typical patriarchal male who imposes authority on her. He says that he loves her but fails to realize that he was objectifying her.

Shayam wonders, "What is she unhappy about?" (M;15). He feels that she speaks 'utter nonsense' when she criticizes him for his greed to accumulate wealth and money. He does not understand when she says that money wasn't everything. Whenever Radha wanted to argue or state her opinion, Shyam silenced her. He always wanted her to look beautiful and well dressed.

Radha knew that Shyam considered her as a mistress and not his wife. She was a 'priced possession' in his house among the other things he owned. Radha says, "Shyam has forgotten that I have lived outside this protected 
world he likes to keep me in". ( M; 14) Shyam tried to confine her and never gave her financial independence. Radha longed for his love and she can be compared to mythological Radha. In Hindu mythology, Krishna leaves Radha. Anita Nair's character Radha too considers herself as the one who was desolated by her husband Shyam. Shyam is another name of Krishna. Nair's Radha longed for Shyam's love and her desire was never realized. Shyam never reciprocated her love. He was materialistic and he forgets about her in his race to accumulate wealth.

Radha says," ...for Shyam, I am a possession. A much cherished possession... he doesn't want an equal; what he wants is a mistress." (M;53) She felt like a trapped butterfly.

Radha also compares herself to mythological Ahalya. Radha meets a foreigner named Chris. Chris had come to Kerala to meet Radha's uncle Koman. Koman was a Kathakali dancer. He insisted Radha to accompany Chris and help him take down notes on his life as a Kathakali artist. Radha gets attracted to Chris. She narrates the story of mythological Ahalya to Chris. Ahalya was the wife of sage Gautama. Once when Ahalya was plucking flowers in her garden, Lord Indra passed by in his chariot. The act of plucking flowers seemed like a gesture of beckoning to Indra. He took the form ogf sage Gautama and spproached her. Ahalya mistook him to be her husband. When sage Gautama returned, he found Ahalya with another man in his form. He got angry and cursed her. She was transformed into a stone and she had to wait for several ages to be redeemed from the curse. Even though Indra was cursed to have a thousand vaginas imprinted on him, he was later forgiven and the vaginas became thousand eyes.

Radha warns herself of the possible outcome of having an extra marital relation. She also knew that it was easier for men to get away with simple or no punishment. She narrates the story to Chris. Radha nurtures a special feeling for Chris. She falls in love with him as he cared for her unlike Shyam. She enjoyed being with Chris and they spoke for longer hours.

Radha thrived on chaos. She hated the way Shyam liked order in everything. While Shyam wanted everything neat and clean, Radha loved chaos. Shyam folded the newspaper neatly after reading it and then folded her paper too. He wore neat ironed clothes and it vexed him to see her closet and bedside table all messed up. She says, "It irritates to see Shyam as he goes regulating his universe and mine." (M:60)

Out of chaos is born order and order is born in Radha's life after the chaos. Radha has no children with Shyam. Shyam's family criticizes her for no fault of hers. She suffers in silence. Radha bears Chris' child in her womb. When she tries to convince Shyam that it was his child, Shyam reveals the truth that he can never father a child.

According to the eminent psychologist and theorist Carl Jung,

The term "archetype" is often misunderstood as meaning certain definite

mythological images or motifs. But these are nothing more than conscious

representations; it would be absurd to assume that such variable representations

could be inherited. The archetype is a tendency to form such representations

as motif-representations that can vary in great deal in detail without losing

their basic pattern. (Man and His Symbols, 58)

Jung explains that something that is of unknown nature is intuitively graspd and is subject to archetypal treatment. Thus the mind does not actively participate in reasoning by conscious thought instead, the archetypal mind steps in. The archetypes thus have their own initiative and specific mind.

In the novel, Radha unconsciously compares herself to mythological Ahalya and Radha. The unconscious fear of punishment surfaces and she takes the archetypal form of Ahalya and Radha.

In the novel Ladies' Coupe', Akhila is brought up as an obedient daughter. She grows up in an orthodox family. She is confined within the limits of customs, tradition and beliefs. Her father, the head of the family considers everyone else in the family as secondary. Akhila's mother too considers herself as inferior to her husband. She waits upon him and serves him. She is a woman who does not have an opinion of her own. The family has food only after the father eats. Akhila is not given her freedom as she was a girl and is restricted to live life in her own terms. Akhila's family considers themselves superior to other castes. Once when Akhila suggests to her mother to give music lessons, she replies that all kinds of people will come to the house. "Brahmins and non-brahmins. Do you think your father will allow such comings and goings on here? Don't you know how strict he is?" ( LC; 13) He wanted a wife to take care of him and his children. He wanted someone who would take care of the house and his needs. Her mother always left her decisions to her husband. She never believed in two equals in marriage.

Akhila's father dies in a road accident but Akhila believes it to be suicide. After her father's death, Akhila is given a job in the office where her father worked. She takes care of the family and plays the role of the head of the family. Even though she works for the family, she is still not given the power to take decisions. Her younger brothers became the decision makers. At the age of forty-five, Akhila embarks on a sojourn journey to Kanyakumari. She escapes from the orthodox Tamil Brahmin life that confined her freedom and individuality. In the ladies compartment of the train, she meets five other women; Janaki Prabhakar, Margarert Shanti, Prabha Devi, fourteen year old Sheela, and Marikolunthu. Each one of them embarks on their own individual journey to their inner self.

Janaki Prabhakar was a contented wife until she realized the value of her freedom. She was a dutious wife and mother but gradually she realizes the she doesn't have an identity of her own. She is forty-five and she always lived under the protected wings of her family. She was tired of being a fragile creature and she says,

I thought if I were to lose it all, I would cope. If I were to become alone, 
I would manage perfectly. I was quite confident about that I think I was

Tired of being this fragile creature." (LC; 23)

Akhila gets to know about Janaki and how she was kept in the protected realm of her husband. Janaki was not contented even though she was taken care of. She was constantly in search of her roots.

Forteen year old Sheela Vasudevan is the youngest of the six women in the coupe'. At a very young age, Sheela learned from her grandmother that it was essential for a woman to satisfy her own self. She tells Sheela,

You mustn't become one of those women who groom themselves to please

others. The only person you need to please is yourself. When you look into a

mirror, your reflection should make you feel happy." (LC;67-68)

Her grandmother dressed with a lot of jewellery every night. She wished to look beautiful even on her deathbed.

Margaret Shanti, the Chemistry teacher is suppressed by her husband Ebenezer Paulraj. Maragret was blinded by her love for Ebe. She obeyed and accepted whatever he said. While she wanted to grow long hair, pursue doctorate and have a baby, Ebe stood against all her wishes. He even made her to abort the life that grew in her. When Ebe insults her inforont of others at a party, she realizes her self-worth and the necessity for freedom. She lives with him and takes revenge on him. She gives him too much food and makes him fat. She thuus crushes his ego. She conquers her fear and inner conflicts.

Prabha Devi's husband Jagdeesh offers her all comfort and delight. She is taken care of and she always felt that she was the luckiest person on earth. Whenshe went to New York, she feels lost in the glamorous world. She decides to dress herself up and attract others. When her husband's friend Pramod was allured by her beauty, she realizes the distress caused by the glamorous life. She was once a virtuous wife and loving mother. She feels guilty and regrets for not having an identity of her own. She conquers her fear and innate timidity.

Marikolunthu was the last woman left in the coupe'. She was abused of body and mind. She was cruelly raped and made to suffer in life. The tragic events eventually makes her to build confidence. She used to surrender her wishes and happiness for others. She finally decides to live her life for herself.

Through the stories of other women in the coupe', Akhila begins to look into herself. She overcomes her fears and understands the meaning of her life. She had been oppressed for many years by her mother, father, and her brothers.

Akhila can be compared to goddess Akhilandeswari or Kanyakumari. Akhila was a spinster like the goddess. She sacrificed her life for the family. It is only at the age of forty-five, she realizes that she never lived for herself. Her love affair with the stranger she met in the train is not realistic. He leaves her and fails to contact her. She gets a one way ticket to Kanyakumari in search of her lost love. Her journey teaches her new lessons in self-trust and identity construction. She realizes her worth and decides to live for herself.

Goddess Kanyakumari also is a spinster. When god Shiva failed to arrive at the right time on the day of their marriage, she decided to live alone. She kills the mighty demon Bana. She was unable to bear the grief and insult caused to her and she destroyed everything she saw. Akhila too kills the demons within her and she asserts her identity and individuality. She clearly understands her role in life and embarks on a new journey towards selfrealization.

Radha and Akhila who are subservient and suppressed by the family, overcome their fear and emerge as independent women. They undergo transformation in life and creates an identity of their own.

\section{References:}

1. Nair Anita, Ladies' Coupe', Penguin Books India, 2001, Print.

2. Nair Anita, Mistress, Penguin Books India, 2005, Print.

3. Campbell Joseph, Goddess: Mysteries of the Feminine Divine, Ed. Safron Rossi, New World Library, California, 2013, Print.

4. Pattanaik, Devdutt, Indian Mythology, Tales, Symbols and Rituals from the Heart of of the Subcontinent, Inner Traditions International, Vermont, 2003, Print.

5. Jung C.G, Man and His Symbols, Dell Publishing House Inc., United States of America, 1968, Print.

6. Jung C.G, Archetypes of the Collective Unconscious, Princeton: Princeton University Press. 1959, Print.

7. Mani Vettam, Puranic Encyclopaedia: Motilal Banarsidass Publishers Private Limited, Delhi, 2010, Print. 